

\title{
How Are Aeromobilities Changing? Reviewing the Literature on European Airports
}

\author{
Jean-Baptiste Frétigny
}

\section{To cite this version:}

Jean-Baptiste Frétigny. How Are Aeromobilities Changing? Reviewing the Literature on European Airports. Mobility in History, 2017, 8 (1), pp.121-128. 10.3167/mih.2017.080114 . hal-01359708v2

\section{HAL Id: hal-01359708 \\ https://hal.science/hal-01359708v2}

Submitted on 14 Jul 2021

HAL is a multi-disciplinary open access archive for the deposit and dissemination of scientific research documents, whether they are published or not. The documents may come from teaching and research institutions in France or abroad, or from public or private research centers.
L'archive ouverte pluridisciplinaire HAL, est destinée au dépôt et à la diffusion de documents scientifiques de niveau recherche, publiés ou non, émanant des établissements d'enseignement et de recherche français ou étrangers, des laboratoires publics ou privés. 
Pre-print version of:

Frétigny, Jean-Baptiste. "How Are Aeromobilities Changing? Reviewing The Literature On European Airports". Mobility in History 8, no 1 (2017): 125-32.

\title{
http://dx.doi.org/10.3167/mih.2017.080114
}

\section{How are aeromobilities changing? Reviewing the literature on European airports}

Jean-Baptiste Frétigny, Université de Cergy-Pontoise, M.R.T.E. research unit

\begin{abstract}
This paper shows that most attention has gone to a linear reading of the evolution of (European) airports in the recent literature, emphasizing contrasted moments of these places. It argues that airports need to be also envisioned as sites of pluralized and changing (aero)mobilities by bridging gaps between the studies of past, present, and future airports as well as between their various monographic investigations. Key political, cultural, social, and economical issues affecting (aero)mobile societies in terms of security, consumption, regulation or bordering can therefore be better understood as complex processes at play in the spatial and temporal connections between airports.
\end{abstract}

Airports seem to be an endless ground for conceiving past and present (aero)mobilities. Understood not only as air mobilities but also as the dominant mobilities of international travel, aeromobilities offer an encompassing understanding of airports as sites of meaningful (im)mobilities of people, objects, ideas, and ideologies. ${ }^{1}$ These sites touch on more power relationships, across far larger and thinner scales of time and space than the ones usually considered in the study of transportation places. As the first review on airport historiography in this journal has showed it, scholars have socially, politically and culturally investigated airports in manifold ways, turning them into key transdisciplinary objects for the development of mobilities studies. ${ }^{2}$ In recent years, studies on European airports have been numerous. Few of these have engaged in deep historical analysis although temporalities play a key role in airports. As spaces they are constantly changing, with terminals themselves being significantly

\footnotetext{
${ }^{1}$ Saulo Cwerner, Sven Kesselring, John Urry (eds.), Aeromobilities (New York: Routledge, 2009); Peter Adey, Lucy Budd, Phil Hubbard, "Flying lessons: exploring the social and cultural geographies of global air travel," Progress in Human Geography, 31:6 (2007): 773-91.

${ }^{2}$ Nathalie Roseau, “Learning from Airport's History”, Mobility in History, 4 (2013): 95-100.
} 
more mobile than planes in terms of design and architecture. ${ }^{3}$ The existing literature misses links between the past and present times of airports.

This decoupling can be related to the linear framing of the evolution of airports that dominates existing literature. In many respects, scholars analysing the history of European airports and beyond have been busy periodising it, emphasizing ruptures between key eras of aero(im)mobilities. Airports until the 1960s are described as balconies or spectacles, as sites of visiting or representations of technological optimism. Post-1960s airports on the other hand are shown in an opposing light. The later airports are described as enclosed and encapsulated, understood as airport cities or as sophisticated apparatuses of surveillance and consumption. The chapters titles focused on the period in synthesis works illustrate this reputation- "The Sterile Concourse: 1970-2000" and "Cities of flight" for instance. ${ }^{4}$

Such readings of airports are relevant in multiple ways. In particular, they help us to better understand how (aero)mobilities, as sets of movements, practices, and representations make sense in the specific context of their times, forming what Tim Cresswell has termed the "constellations of mobilities." However, this review of recent works pleads for further connections between research on the present and past times of airports. Such linkages will allow us to explore aeromobilities in more depth and address new questions and work in this vein is occurring within the subject of European airports. Often tied to places beyond the region, European airports offer pluralized as well as spatially and temporally situated accounts of aeromobilities. More than a firmly consistent and homogeneous world region, this fragment of the Global North turns out to be a laboratory of aeromobile constructions, be they mobility systems, regimes, commodifications, or experiences. Each of these contributes to the creation of multiple territorial constructions. The first part of the essay stresses the significance of historicizing the conception of contemporary airports as airport cities. This is a critical focus in light of studies that have discussed the territorial moorings of airports and the social and economic diversity engaged in these places. The territoriality of these aeromobile places is further discussed in the second part which calls for a better understanding of the historical processes of bordering and surveilling (aero)mobile societies through European airports. Finally, the review questions the thrown-togetherness of people at European airports as a way to critically understand the historical construction of aeromobile societies.

\footnotetext{
${ }^{3}$ Hugh Pearman, Airports: A Century of Architecture (London: Laurence King, 2004), 17; Peter Adey, "If mobility is everything then it is nothing," Mobilities, 1:1 (2006), 84-85.

${ }^{4}$ Alastair Gordon, Naked Airport: A Cultural History of the World's Most Revolutionary Structure (Chicago: University of Chicago Press, 2008), 217-259; Pearman, Airports, 197-233.

5 Tim Cresswell, “Towards a politics of mobility," Environment and planning D, 28:1 (2010): 17-31.
} 


\section{Territorial strategies and dynamics of airports: how new are airport cities?}

Scholars have stressed the contemporary diversification of social and, more especially, economic activities engaged at airports or in their surrounding territories. Such processes have been decisive in the labeling of airports as airport cities or even aerotropolis by some researchers and airport stakeholders, presenting them as the decisive sites for the future of urban life and development. ${ }^{6}$ Historical works help contextualize such claims and recent studies of the projects of urbanists in the $20^{\text {th }}$ century clearly show that current and imagined airport developments are far from new. Nathalie Roseau, in particular, has revealed that airports have played a key part in the future planned for cities both in American and European contexts. ${ }^{7}$ New historical analysis could thus more explicitly intersect with and critically engage the discussion of contemporary airports and their related strategies of development.

An invigorating position for envisioning the historical continuities between past and present airports regards the economic aspirations of the places and their importance as sites of sociality. Most scholars point to the disappearance of visitors observing the planes from the balconies during air shows or during the weekend after the 1960s as a sign of declining sociality and economic diversity. ${ }^{8}$ Peter Adey, on the other hand, suggests the endurance of both of these practices. Drawing on the example of Liverpool, he stresses the dynamism of social activities associated with the airport, related to its support society, spotters and school trips. ${ }^{9}$ The study of other airports, such as Frankfurt and Amsterdam Schiphol, supports the idea that airports, as places of spectacle are far from having totally disappeared. If the sociality of contemporary airports has been mostly described as normative and policy driven, other experiences need to be documented as potential alternatives to the dominant commodification of aeromobilities.

In spite of the significant environmental nuisances airports produce, growth strategies and hopes for additional development are as central to growing contemporary airports as they

\footnotetext{
${ }^{6}$ Stephen J. Appold, John D. Kasarda, "The airport city phenomenon," Urban Studies, 50:6 (2013), 1239-59; John Kasarda, Greg Lindsay, Aerotropolis: the way we'll live next (New York: Farrar, Straus and Giroux, 2009).

${ }^{7}$ Aerocity: quand l'avion fait la ville (Marseille: Parenthèses, 2011).

${ }^{8}$ See note 3. See also Lucie Demettre, "Entre clôture et enfermement : la bivalence de l'espace aéroportuaire," Cahiers de l'ADES, 4 (2009), 113-24;"Quand l'aéroport devient ville : géographie d'une infrastructure paradoxale," (Ph.D. dissertation, Bordeaux University, 2015) ; Lucy Budd, "Airports: From flying fields to twenty-first century aerocities," in Ben Derudder et al. (eds.), International Handbook of Globalization and World Cities (Cheltenham: E. Elgar, 2012), 151-61. On the first period, particularly studied, see Vanessa R. Schwartz, "Dimanche à Orly: The Jet-Age Airport and the Spectacle of Technology between Sky and Earth," French Politics, Culture \& Society, 32:3 (2014): 24-44.

${ }^{9}$ Peter Adey, "Airports and air-mindedness: spacing, timing and using the Liverpool Airport, 1929-1939," Social \& Cultural Geography, 7:3 (2006): 359-60.
} 
were to those in the past. ${ }^{10}$ Such aspirations have applied not only to individual airports, but were also essential to circulation between airports. The erection of airports geared toward serving other airports has been studied in the case of Amsterdam Schiphol's role in changes brought to the design of Terminal 4 at John F. Kennedy airport. ${ }^{11}$ Such studies clarify the movement of ideas, policy mobilities, and models between interconnected airports with more historical depth. The historical studies of European airports occasionally mention such mobilities, stressing the role played for instance by the architecture of Hamburg and Schiphol for Liverpool airport. ${ }^{12}$ But more encompassing analysis is needed to understand these exchanges, producing comparative and multi-sited research that reach beyond usual approaches.

Investigating such spatial and historical connections is also paramount to understanding the local, regional, and national notions of 'air-mindednesses' and the demonstrations of pride, hope, or hostility of actors associated with airports. What can common expressions of enthusiasm and unity around Speke in the 1930s, Schiphol between 1916 and 1940, or Orly in the 1960s tell us about the position of such projects within Europe $?^{13}$ What do they tell us about the politicization of aeromobilities? And how can they be connected to the construction of current airports or to more ambivalent relationships towards airports? Such ambivalent attitudes are tied to the privatization process of air transportation and airports initiated in the 1980s in Europe, which arouses concern that strategic gateways falling into private hands might compromise the territorial interests attached to them. ${ }^{14}$ Questioning the changing urbanity and territoriality of airports pleads for a critical attention to the historicity of so-called airport cities by developing more overarching, diachronic and synchronic analysis of social and economical activities at stake in airports. The challenge is to combine relatively large spatial and temporal scales of comparisons with a micro-scaled attention to the design, practices, experiences, representations or atmospheres associated with airports in order to comprehend their

\footnotetext{
${ }^{10}$ Jean-Baptiste Frétigny, "Les mobilités à l'épreuve des aéroports : des espaces publics aux territorialités en réseau," (Ph.D. dissertation, Paris 1 Panthéon-Sorbonne University, 2013) : 181-190.

${ }^{11}$ Koos Bosma, Anna Nikolaeva, "Farewell to Spectacular Simplicity?" in Koos Bosma (ed.), Megastructure Schiphol: Design in Spectacular Simplicity (Rotterdam: nai010 publishers, 2013) 298-306. See also Rachel Bok, “Airports on the Move? The Policy Mobilities of Singapore Changi Airport at Home and Abroad," Urban Studies, 52:14 (2015)L 2724-40.

12 Adey, "Airports and air-mindedness," 343-63.

13 Ibid., 343-63, Abdel El Makhloufi, Harm Kaal, "From Airfield to Airport: An Institutionalist-Historical Approach to the Early Development of Amsterdam Airport Schiphol, 1916-1940," Journal of Urban History, 37:4 (2011), 497-518, and Schwartz, "Dimanche à Orly", 24-44.

14 Heiner Stahl, "Preparing for Landing, Ready for Take-Off. Zoning Noise Pollution as Spatio-Temporal Practices at Berlin-Tegel and Berlin-Tempelhof Airport (1965-1975)," Historical Social Research, 38:3 (2013): 229-45; Donald McNeill, "Behind the 'Heathrow hassle': a political and cultural economy of the privatized airport," Environment and Planning A, 42:12 (2010): 2859-2873.
} 
kaleidoscopic sense of place which shapes aeromobilities. This can be said of issues of security and borders at airports as well.

\section{Surveillance and bordering at the airport: grasping historical and spatial changes}

If numerous works focus on the apparatuses of security in airports, seen as epitomizing the advent of the surveillance society, these works less effectively document the changing spaces and spatialities of such apparatuses. A few new works show the assemblage and changes of a genuine mobile border produced throughout airport terminals, evolving with the formation of the Schengen area, its extension to new countries, or changes in drug policies. ${ }^{15}$ Such pieces argue for a better understanding of historical processes of control, be they geopolitical, technological or more anthropological. Can we compare, for instance, the processes of militarization of airports today with the part played by past airports in military conflicts? ${ }^{16}$ Such reflection on control concerns airports, but also moves beyond. Studying the effective spatial and temporal diffusion of these apparatuses in direction of other places would be of great interest.

How has the experience of passing over an air border or its past and current descriptions evolved $?^{17}$ How can we also understand the strength and the violence attached to airport borderings with more historical depth? Works on present and often dramatic situations of refugees and migrants at airports, in relationship with the policies of a fortress Europe, need to be put in perspective in such ways as we know little about past practices of detention in - and deportation from - airports. The process of patrimonialising airports, of making them a part of heritage, has been linked to their architecture. ${ }^{18}$ But their historical role as migrant gateways requires further investigation. It would facilitate the recognition of such sites as key memory places for European societies, which seems to be silenced today, in striking contrast with other

\footnotetext{
15 Jean-Baptiste Frétigny, “Air Travel Opens New Understanding of Borders,” Annales de géographie, 690:2 (2013), 151-74; Sanneke Kloppenburg, "Mapping the Contours of Mobilities Regimes," Mobilities, 8:1 (2013): 52-69; Tim Cresswell, "The Production of Mobilities at Schiphol Airport, Amsterdam," in On the Move: Mobility in the Modern Western World (London: Routledge, 2006), 219-58.

${ }^{16}$ Regarding the militarization of airports, Mark Dierikx, Civil Aviation in Europe: A History of Schiphol Airport (Manchester: Manchester University Press, 1997); Sonja Dümpelmann, Flights of Imagination (Charlottesville: University of Virginia Press, 2014).

${ }^{17}$ Julian Pitt-Rivers, “Un rite de passage de la société moderne : le voyage aérien”, in Pierre Centlivres, Jacques Hainard (eds.), Les rites de passage aujourd'hui (Lausanne: L’Âge d'homme, 1986), 115-30; Frétigny, "Air Travel,"151-174.

${ }^{18}$ Roseau, Aerocity, 272-82.
} 
sites such as Ellis Island for sea mobilities. ${ }^{19}$ Historicizing the migratory practices at EU airports, ${ }^{20}$ often studied in stimulating ways in the rest of the world, ${ }^{21}$ would give a better knowledge of Europe by comprehending its mobile co-construction with the rest of the world, or to put it in another way, by provincialising it to avoid European ethnocentrism. ${ }^{22}$ As the example of migrants shows, addressing political issues at stake through the changing spaces of airports is as much about security and territorial limits as it is about the diversity of an airport public, or those people practicing aeromobilities.

\section{Aeromobile societies and the changing public of airports}

Only a few studies specify how being an air traveller today is still an experience largely undistributed from its past forms, most notably in terms of social class or gender ${ }^{23}$ Little is known about the changes in the social composition of aeromobile public. The title adopted almost forty years ago for the last chapter of a Social History of Air Travel, "The Age of Mass Mobility?," remains in many respects an unanswered question. ${ }^{24}$ The public discourse points at a "democratisation" of air travel, conceived as a given more than a process. It needs to be addressed through a broader analysis of the accessibility of aeromobilities and airports, for which Europe provides an interesting case study.

The changing diversity of the airport public over time is one of the key questions that aeromobile studies of airports need to address. One lead followed up by a pioneering work concerns the place of children within airports, depicted as integral to demonstrations of local

\footnotetext{
${ }^{19}$ Nancy Green, “Trans-frontieres : Pour une analyse des lieux de passage,” Socio-anthropologie, 6 (1999).

${ }^{20}$ Kathy Burrell, "Materialising the Border: Spaces of Mobility and Material Culture in Migration from PostSocialist Poland," Mobilities, 3:3 (2008): 353-73; Kathy Burrell, "Going steerage on Ryanair: cultures of migrant air travel between Poland and the UK," Journal of Transport Geography, 19:5 (2011): 1023-30; Maria Abranches, "When People Stay and Things Make Their Way: Airports, Mobilities and Materialities of a Transnational Landscape," Mobilities, 8:4 (2013): 506-27.

${ }^{21}$ Brenda Chalfin, "Sovereigns and citizens in close encounter: Airport anthropology and customs regimes in neoliberal Ghana," American ethnologist, 35:4 (2008): 519-38; Sanneke Kloppenburg, Peter Peters, "Confined Mobilities: Following Indonesian Migrant Workers on Their Way Home," Tijdschrift voor economische en sociale geografie, 103:5 (2012), 530-41.

${ }^{22}$ Chakrabarty Dipesh, Provincializing Europe (Princeton: Princeton University Press, 2000).

${ }^{23}$ Jean-Baptiste Frétigny, "La mobilité naturalisée par les lieux de passage : étude de la publicité à l'aéroport de Roissy Charles-De-Gaulle," Regards Sociologiques, 45-46 (2013): 47-69; Saulo Cwerner, "Introducing aeromobilities," in Saulo Cwerrner, Sven Kesselring, John Urry (eds.), Aeromobilities (New York: Routledge, 2009), 10.

${ }^{24}$ Kenneth Hudson, Julian Pettifer, Diamonds in the Sky. A Social History of Air Travel (London: Bodley Head, 1979).
} 
and national air-mindedness and, more recently, to the ideologies of surveillance encapsulated in airport games. ${ }^{25}$ But we know very little of the past of other minorities at airports, of their practices within these places, or about the related processes of inclusion and exclusion they experienced. Homeless people ${ }^{26}$, linguistic minorities ${ }^{27}$ or protesters engaging political actions $^{28}$ for instance have been significantly more identified in works on contemporary European terminals than in the past. Their historical contextualization would shed light on exclusionary and transgressive practices associated with changing (aero)mobile societies. Airports have been understood as key places for asserting the power of dominant stakeholders, ${ }^{29}$ epitomized by German airports during Hitler's reign. But they can also be seen as places where changing and enduring power relationships cut across publics in terms of social classes, gender, race, (dis)ability, etc.

\section{Conclusion}

This review shows that recent historiography on European airports can pave the way for stimulating research on aeromobile worlds more broadly. Its confrontation with works on contemporary airports emphasizes continuities and not only ruptures between past and present. The European case shows more broadly that historical, contemporary, and future airports, as intersecting places, are too interrelated for corresponding studies to be kept apart. Past airports can be better understood through the prism of bordering, social access, segregation, and migratory experiences of passengers. Beyond their stated futuristic modernity, contemporary airports need also to be read as inherited places and palimpsests of past aeromobilities. Envisioning future airports requires more analysis of their (dis)junctions with the genealogy of imagined airport cities. Understanding the formation of aeromobile societies therefore invites us to fill the gap by establishing more and more diachronic as well as synchronic and spatial connections between airports. Indeed, thinking critically on changing aeromobilities involves not only paying more attention to temporal processes and possible continuities but also to

\footnotetext{
25 Adey, "Airports and air-mindedness," 343-63; Peter Adey, "Airports for Children: Mobility, Design and the Construction of an Airport Education,” Built Environment, 33:4 (2007): 417-29.

${ }^{26}$ Cresswell, "The Production of Mobilities," 248-51 and Bruno Proth, Isaac Joseph, "La "mise en demeure" d'un aéroport parisien par trois SDF irréductibles," L'Homme et la société, 1:155 (2005):157-180.

27 Adam Jaworski, Crispin Thurlow, "The (de-)centering spaces of airports," in Sari Pietikäinen, Helen KellyHolmes (eds.), Multilingualism and the Periphery (New York: Oxford University Press, 2012): 154-98; Alexandre Duchêne, "Néolibéralisme, inégalités sociales et plurilinguisme," Langage et société, 136:2 (2011): 81-108.

${ }^{28}$ Jean-Baptiste Frétigny, "La conflictualité de la ville en mouvement au regard d'espaces publics métropolitains émergents : les aéroports," in Didier Desponds, Elizabeth Auclair (eds.), La ville conflictuelle (Paris: Le Manuscrit, 2016).

29 David Pascoe, Airspaces (London: Reaktion Books, 2001).
} 
spatial contrasts between airports that confront multiple situations and trajectories of regulation, commodification, control, and practices of mobilities.

Jean-Baptise Frétigny is Associate Professor in Geography at the Université de CergyPontoise and member of the MRTE research unit. His research interests concern the experiences and power dynamics associated with mobilities and public spaces, paying attention to their control, their alternative practices and their digital dimension by using mixed methods. 